\title{
Obstacles of Administrative Creativity Among the Principals of Public Schools in Amman City from their Point of View
}

\author{
Dr. Mammon s. alzboun \\ Asma'a f. Al Zubaidi \\ Nour r. Momani \\ School of Educational Sciences, The University of Jordan, Amman, Jordan
}

\begin{abstract}
The aim of this study is to identify the obstacles of administrative creativity among the principals of public schools in Amman City from their point of view. With that, the descriptive survey methodology was adopted. The sample of the study consisted of (105) male and female principals selected randomly. To achieve the objective of the study, a 30-item questionnaire distributed over (3) areas was formatted.The results of the study showed that the obstacles of administrative creativity among the principals of public schools in Amman City from their point of view for various fields were at a medium degree, where the field of environmental obstacles ranked first, followed by the field of organizational obstacles in the second place, followed by the field of personal obstacles in the third and last rank.The results showed that there were statistically significant differences for both sex variable in favor of males and experience variable in favor of those with more than ten years of experience.In the light of the researcher's findings: Work to link social and cultural institutions in the community in order to unite efforts to contribute to raising awareness of community members of the importance of creativity and innovation in school work, and organize programs and training courses to develop creativity skills. Promote positive communication at all levels to facilitate proposals for the development and improvement of performance, and the need to provide integrated administrative staff in each school to reduce school workload and provide an opportunity for creativity and innovation.
\end{abstract}

Keywords: Administrative Creativity, Obstacles, Principals, Amman City.

DOI: $10.7176 / \mathrm{JEP} / 10-36-04$

Publication date: December $31^{\text {st }} 2019$

\section{Introduction}

The current age is witnessing an information revolution in all areas of life and tremendous technological progress in light of global development, so it became known as the era of globalization and openness, and this has been reflected on organizations as part of this world, and found itself facing many challenges and new and accelerating developments that threaten its survival as no new ways and means are found Mechanisms to cope with these developments and challenges and adapt to them. Modern organizations in developed countries have realized that the solution lies in reviewing their policies, methods, organizational culture, and administrative systems followed, by convincing managers to work with the imperative to shift from traditional administrative construction to Democratic building and more open and resilient participation, with special attention being paid to the human element.

Thus, educational institutions face many variables and challenges, in light of the intense competition, and the complications that occurred in their systems, which necessitated updating, changing and developing their administrative policies and systems, and their methods of work in order to fit with the challenges that arise, and the development process in these institutions lies in the process of developing its management. Administration has become an important artery in contemporary societies, and an essential pillar in the consolidation of these social systems, and in the rule of security and safety, discrimination and creativity. Therefore, it has become an imperative for institutions to face major challenges by finding modern methods that keep pace with the tremendous developments in raising organizational efficiency (Al-Omari, 2015).

In recent years, creativity has become a subject of growing interest in the educational environment, and the development of creativity is increasingly seen as an educational necessity because it encourages the performance of individual students and affects their future success (Castillo-Vergara, 2018).

Hence, the various institutions have given creativity unique importance, exerting moral and financial effort, and adopting modern tools, methods, methods and policies that develop the creative capabilities of workers, certain of the importance and benefit of developing capabilities among workers, which helps in the progress of the individual at the individual and collective level, and working to increase Competitiveness and friendliness of employers (Al-Muhailbi, Al-Azmi and Al-Qahtani; 2014)

Creativity is one of the indicators of human quality, and creativity and creativity in schools can be created and integrated into a good management framework, through managers who are able to build and develop an innovative and sustainable creative culture (Yuliana, 2007). If all teachers and students participate and interact well, a pleasant work environment and mutual respect will greatly influence the school life as a whole (Sagala, 
2013). Because leadership is the principle of quality management, its importance for education must be understood, the difference between leadership and management, effective communication in creative leadership, and the difference between competition and cooperation (Cretu, 2015). Therefore, the manager must possess three management skills, which are: conceptual skills; technical skills; and human relations skills (Kempa, 2015). According to Hiso and others, school principals who provide creative education must be creative and innovative in order for schools to compete and grow (Hsiao, Chang, and Chen, 2014). In addition, Al-Khasawneh (2011) revealed that changes in both educational policy and teaching practices can help employees and students achieve creativity. Therefore, school principals should motivate teachers and students to introduce innovative classroom activities.

And if creativity is an urgent necessity, one of the most important things and duties that an effective director must approach is to think and innovate how to develop his school performance, which is reflected in the development of the performance of his employees, by providing them with expertise and ingredients that will develop their institutional performance and increase their effectiveness, production and love for work. As the headmaster's work is the actual test of all educational administration policies, and the face is effective, it must have the ability to be creative at work and find new creative and innovative opportunities, because creativity helps in providing new perceptions, and this requires that his administration be creative, and able to face challenges Diverse, and increasing their enthusiasm for change and modernization, and it must transcend the usual ways and face challenges and changes, and secure the appropriate atmosphere to blow up talents and creativity in order to make a qualitative shift in his school, as there is no sense in developing and modernizing education without making real changes in capabilities, directions, values and loan And practices of the leaders of change (Bettayeb 2015).

Creativity has become an essential characteristic of the school principal who is responsible for achieving educational and educational goals at the level of administration in light of the rapid changes and challenges and conditions faced by the current era, he must demonstrate flexibility, renewal, innovation, fluency, a sense of problems and awareness of weaknesses The palaces and dealing with situations creatively, and his awareness of the details about the ideas that revolve in the mind, and the issue of administrative creativity is one of the important and new topics that calls on leaders to abandon routine work and progress towards creativity, innovation and access Li knowledge as soon as possible as much as possible at the lowest cost and easy ways (Zyoud 2012).

And administrative creativity is one of the most important factors that educational institutions pay attention in the field of the educational process, and learning in light of competition between these institutions for survival and excellence. Educational institutions encourage creativity and urge it to achieve it as a primary goal. Successful education requires achieving an educational leader and director responsible for his educational role in keeping pace with creativity. He must be courageous to achieve qualitative education that provides individuals with confidence, and to be open to the continuity of creativity (Al-Omari, 2015).

The creative director is the manager who has the ability to break the routine, leave the usual practices, get rid of them, and introduce methods, tools, methods and ideas that will develop the school and its employees, and has the ability to search for creative ideas in all the sources that he can reach, both within the walls of his school, and from He works with him, or from other institutions, or benefit from the experiences of his colleagues, and he has the ability to implement creative ideas and subject them to experimentation to encourage their owners, increase his ability to plan and work within one team, and work on innovation and creativity by directing the school towards change And creativity in order to prepare a creative study in its various works, and it has the ability to deal with problems and issues, and work to solve it by collecting information and interpreting it at the lowest costs and the best ways, and to have adaptation, experimentation and innovation that are among the characteristics that the creative director should possess (Anjoud, 2008 ).

From Wong \& Davey (2007) point of view, the main challenge for creative leadership is how to develop creators in the organization by creating a positive business climate and providing opportunities for innovation and risk tolerance to deal with future uncertainty (Handoyo, 2011).

There are problems and obstacles to managerial creativity among school principals, as they lack many administrative management skills. Among the most important obstacles to achieving administrative creativity in public education schools are the literal commitment to regulations and laws, the incentive system of both material and moral types, insufficient financial return, central decision-making, lack of creative leadership for management, lack of internal motivation for creativity and ignoring creative opinions And the absence of freedom and democracy (Al-Sarayrah, Al-Majali, Salah, and Al-Asasamah, 2012).

Creativity is defined as the interaction between efficiency, process, and the environment in which an individual or group produces a tangible new and useful product as defined in a social context (Plucker et al., 2004). When referring to organizations, Talbot (1997) defined creativity as "a change that sticks to it (for a period of time)." (Puccio, Mance, and Murdock, 2011) added that creativity is the production of original ideas that serve a purpose, and simply defines creativity as Producing new and useful ideas in any field, although the 
choice of words and the context of definitions differ, almost all of them include an idea of something that was not seen or made before it was also functional in a context. This means that creativity is judged, in part, by the environment Surrounding it (Plucker et al., 2015).

While Waer (2017) defined creativity as the mental process through which the creative work can be visualized, that is, the way in which a person creates creativity in his work, and this method has different stages through which the creator reaches new and original works, and he is defined as the meeting point between three Key elements are motivation, resources and techniques (Al-Zuyoud, 2012). Creativity is also defined as the human truth that enables the individual to understand and develop the surrounding ideas, things or methods, and that it is a mental work whose beginnings are individual and are strengthened through the group, where these ideas are characterized by novelty, originality, flexibility and out of the ordinary, benefiting both the individual and the group And the institution as well as the community (Rosenfield, 2015).

Countries seek to develop their educational systems and institutions, especially those working at all different levels, as an important tool in achieving educational goals, and work to prepare them well and qualify them, which provides them with the ability to face the challenges that they will face by working to raise their creative competencies and highlight their ability to them To develop the educational institution and reach the desired goal with the least efforts and costs, through the use of modern methods, tools and administrative means, in order to develop the desired future vision for the educational system, because the modern educational system is a dynamic system $\mathrm{m}$ Evolution has the ability to keep pace with developments, and believes in creativity and excellence (Khassawa, 2011).

In spite of the importance of administrative creativity in educational educational institutions, there are obstacles that prevent its development, and this is represented in the weakness of its administrative procedures such as planning, implementation, follow-up and evaluation on the one hand, and a few incentives related to disrupting creativity, the weakness of the continuous evaluation process, and the existence of a dictatorial leadership that does not encourage On creativity, the lack of cohesion of the efforts of the work team to develop the level of performance of their organization on the other hand, weak review of the systems, laws and instructions that govern these institutions on the third side, the inability to perceive weaknesses and imbalances, and the lack of adopting positions based on evidence and correct information due to lack of investigation in the country Time and objectivity (Jamaan, 2014).

Handoyo (2011) listed a set of obstacles that would prevent the application of creativity in educational institutions and reach the desired goal, such as mental disabilities, emotional disabilities, impediments, environmental and organizational constraints.

And the presence of many and various obstacles or obstacles that prevent the development of creative thinking or access to the creative process to the products of scientific, literary or artistic value for society. Means of developing administrative creativity as described by TOYOTOK, 2016.

Personal impediments: These are impediments related to the individual person himself, which result in the influence of the surrounding environment, which may arise with the individual since his childhood, such as: weak self-confidence, and weak confidence in others leads to the rejection of what they initiate by proposing, and the officials 'resistance to change, and avoiding inquiries about known things For fear of embarrassment, excessive enthusiasm and rushing results, the inability to take risks and hesitation in presenting unfamiliar ideas, the desire to avoid failure, a tendency to depend on others, reluctance to display unfamiliar ideas, avoiding ambiguity and lack of clarity, and weak confidence in others leads to Reject what initiates $\mathrm{N}$ being put suggestions, and personal care to comply with the instructions, focus effort on the difficult and neglect of minor problems, and lack of interest in finding new solutions to the problems.

Organizational impediments: These are the obstacles resulting from the organization from which the individual works, such as laws and institutional systems, policies, goals, procedures, organizational structure, management philosophy, authority pattern, leadership style, and communication systems used. Others may act as obstacles in the way of creativity. Organizational obstacles include: the scarcity of programs and training courses on creativity and innovation skills at work, the lack of moral incentives for owners of new positive ideas, the absence of officials' appreciation of the importance of the work team as a method for proposing new ideas and appropriate solutions to problems, and affirming the literal commitment to applying laws, and the limited freedom to complete school work, And the lack of encouragement to experiment with new methods of running the school and solving its problems.

There are many studies that examined the obstacles to applying administrative creativity. Ozmen and Muratoglu (2010) conducted a study in Turkey aimed at identifying the creative competencies of school principals, especially in the field of applying knowledge and management strategies. The study showed that the most important creative competencies that a manager must possess are: effective knowledge management, the ability to form an effective work team, the practice of administrative communication, the formation of social support networks, and organizational and management competencies. The study showed that there were no statistically significant differences between males and females in perceptions about the nature of the creative 
competencies that the principal of the school should possess. Athanasoula, Ripa, Makri, Kalliopi, and Vascars (Athanasoula, Reppa, Marki, Kalliopi and Psycharis, 2010) conducted a study in Greece aimed at identifying the level of managerial creativity among school principals and its effect on the communication between the school and parents. The study showed that the level of creativity of the principal of the school is the most important factor in establishing channels of communication with the family. The study also showed that manifestations of creativity with the principal include direct contact with the guardian, informing the guardian of the problems that impede the education of his children, discussing current and future school plans and accept Ideas and criticism from the guardian. Al-Harthy (2012) conducted a study titled "The reality of applying the elements of administrative creativity to secondary school principals from the point of view of principals and agents, and identifying organizational and personal obstacles and cultural and social obstacles to administrative creativity in secondary school principals, and the study showed that there are no differences between the averages of the responses of the study members from Obstacles to administrative creativity among the directors of government secondary schools in the governorate of Jeddah, according to the variables of gender and experience. As for the variable of the Education Office, there are statistically significant differences in favor of the directors who follow the Education Office in Jin B, the Office of Education in the north, and the presence of statistically significant differences due to the scientific qualification for the benefit of graduate studies. Al-Omari (2015) conducted a study aimed at identifying obstacles to administrative creativity among school principals in the Department of Education in Al-Makhwah from their point of view. , And the presence of statistically significant differences attributed to sex in favor of males. Al-Otaibi (2018) conducted a study aimed at identifying obstacles to administrative creativity among leaders of government schools in Afif Governorate, where the study was limited to personal and organizational obstacles in administrative creativity, in Afif Governorate, and the study concluded that the respondents' estimates on the axis of organizational constraints were high, And on the red of personal handicaps was average. For this, the need arises to support administrative creativity and to reveal the obstacles that stand in the way of its realization. From this standpoint, this study came to identify the obstacles of administrative creativity among government school principals in the university district from their point of view, and then put some recommendations and proposals to confront these obstacles in the hope of developing and improving schools and their outputs.

\section{2. the study Problem}

The issue of administrative creativity is one of the important topics, because it has importance for the individual and society. The manager in the current era requires him to show several qualities such as creativity, innovation, effective leadership, and continuous development, and facing obstacles that may prevent the educational institution from reaching its educational goal.

The school administration has to have clear thinking and vision in order to achieve the desired goals from it and reach the best desired results, but the obstacles, problems and challenges facing school principals remain one of the most important things that stand in front of them, because they have a clear impact in stopping the process of creativity and reducing them, and these Challenges and obstacles vary from school administration to another (Al-Tayeb, 2015).

Many studies and studies have confirmed the low level of administrative creativity such as the study AlSalami (2012), the study of Al-Harithi (2012), the study of Al-Enezi (2018), and Al-Otaibi (2018). These studies revealed the need to study the obstacles of administrative creativity to develop proposals that can contribute to reducing Including, developing and raising its level.

There are a few studies that address administrative creativity and its impact on workers in the creative education sector compared to creative organizations. As Vasco tracked the history of administrative creativity in schools from 1985 to 2015 and concluded that more research should be done in the field of creativity in terms of learning methods, student interest, teacher attitudes, administrators, and barriers to benefiting from administrative creativity and proper employment. There are relatively few articles that discuss schools as creative in the general sense and even fewer seek to define creativity (Fasko, 2015)).

In view of the importance of this topic, this study was an attempt to identify the obstacles of administrative creativity among principals of public schools in the university district from their point of view.

\subsection{Study Questions}

The present study seeks to answer the following questions:

- The first question: What are the obstacles to administrative creativity among school principals in the university district from their point of view?

- The second question: Are there statistically significant differences at the degree of significance $(0.05 \geq \alpha)$ between the averages of government school principals in the university district regarding the obstacles to administrative creativity attributable to the variables (gender, experience)? 


\section{Objectives of the study}

The study attempted to achieve the following goals:

- 1 Knowing the obstacles of administrative creativity to the principals of public schools in the university district.

- Disclose differences in the obstacles to administrative creativity according to the variable of gender and experience.

\section{4. the importance of studying}

The importance of the study lies through:

- As one of the new important topics that requires managers to ignore routine, move towards creativity and innovation, and obtain knowledge as quickly as possible, at the lowest cost and easiest way.

- It is expected that the directors of schools and workers in the Ministry of Education will benefit from the results of this study by identifying the obstacles of administrative creativity facing them, which negatively affect their work, which encourages them to develop new plans that enable them to lead their schools efficiently and competently.

- It may be of importance in planning and preparing training programs for school principals; to include these programs as training materials related to developing creative thinking skills and creative methods in problem solving and decision making.

- It may contribute to raising awareness of the importance of creativity in developing work, and how to address the obstacles that may limit creativity among managers, and raise the level of their creative thinking and productivity in work, as well as know the nature of administrative creativity and its importance and role in developing school performance and achievement, and achieve its goals better .

\section{The limits of the study}

This study was limited to the responses of the principals of public schools in the university banner about the obstacles of administrative creativity, the time period during which the study tool was applied, which is the first semester of the academic year 2020/2019.

\section{Terminology of study}

Administrative creativity: Al-Qaryouti (2003) defines him as collective institutional creativity, which is more general and comprehensive, meaning the ability to find ways, tools, methods and ideas that can receive the best response from workers, and works to motivate them to invest their capabilities and talents to achieve the goals of the organization. It is intended in this study: The principal of the school practices administrative work with a different thought and style, which creates a positive atmosphere for working individuals with the aim of creating new ideas and deviating from the ordinary in solving problems and overcoming the usual methods of thought and work in pursuit of school efficiency.

Obstacles: it is the handicap in the language that means "imprisonment and exchange (Turquoise Abadi, 1987). And idiomatically: they are the problems or organizational, personal, environmental, or social obstacles and ambiguities that prevent achieving the desired goals adequately and effectively (Skarna, 2011). Researchers score procedural impediments to administrative creativity: It is the total score for the response of individuals in the study sample to the dimensions of the scale of administrative creativity constraints for government school principals in the university district, used in this study.

\section{Study methodology}

The descriptive survey method was used to achieve the goals of the study to find out the obstacles of administrative creativity among the principals of public schools in the university district from their point of view.

\subsection{Study community}

The study population consisted of all employees of government schools, from the heads of public schools in the university district from their point of view, and they numbered (150) male and female principals.

\subsection{The study sample}

As for the study sample, it was chosen according to the random sample method, which gives each individual in the study community equal opportunities. The number of the sample population was (105) male and female principals, among high school principals who work in government schools in the university district. Table (1). 
Table (1): Frequencies and percentages according to the study variables

\begin{tabular}{|l|l|l|}
\hline \multirow{2}{*}{ gender } & Categories & Repetition \\
\cline { 2 - 3 } & male & 50 \\
\hline \multirow{3}{*}{ Experience } & female & 55 \\
\cline { 2 - 3 } & Less than 5 years & 35 \\
\cline { 2 - 3 } & From 5- less than 10 years & 37 \\
\cline { 2 - 3 } & 10years and over & 33 \\
\hline & total & 105 \\
\hline
\end{tabular}

\subsection{Search tool}

The research tool consisted of a questionnaire that the researcher prepared, to know the degree of the existence of obstacles, administrative creativity among the principals of public schools in the university district based on the results of the exploratory study and previous Arab and foreign studies such as Al-Zyoud Study (2012) and Khasawneh Study (2011).

\subsection{Certify the tool}

To ensure the validity of the tool, it was presented to a group of (15) arbitrators from the University of Jordan, the Hashemite University, Al Al-Bayt University and the University of Islamic Sciences in the field of educational management, measurement, evaluation, psychology, and educational guidance to judge the appropriate degree of paragraphs.

\subsection{The stability of the tool}

The study tool was applied to an exploratory sample from outside the study sample consisting of (40) managers and directors, by calculating the internal consistency coefficient according to the Gronbachs Alpha equation for each field of study, and for the tool as a whole, where the stability of the tool as a whole reached (0.88) And for the dimensions (0.86-0.88), and Table (2) shows these parameters, and these values were considered acceptable for the purposes of this study.

Table (2) coefficient of internal consistency of Cronbach Alpha
\begin{tabular}{|l|l|}
\hline Obstacles to administrative creativity & Internal consistency \\
\hline Personal handicaps & 0.88 \\
\hline Regulatory constraints & 0.86 \\
\hline Environmental constraints & 0.87 \\
\hline Tital instrument & 0.88 \\
\hline
\end{tabular}

\section{Presenting and discussing the results:}

Below are the results related to each study question according to the different fields included in the study tool, and the results were as follows:

The first question: What are the obstacles to administrative creativity among school principals in the university district from their point of view?

To answer this question, arithmetic averages and standard deviations for the obstacles of administrative creativity have been calculated among the principals of public schools in the university district in general and for each field of the study tool, and Table 3 shows that.

Table (3) arithmetic averages, standard deviations and rank for the study sample estimates of the dimensions of administrative creativity obstacles

\begin{tabular}{|l|l|l|l|l|}
\hline Level & standard deviation & Mean & Dimensions of obstacles to administrative creativity & Rank \\
\hline Medium & 0.97 & 3.50 & Environmental constraints & 1 \\
\hline Medium & 0.88 & 3.49 & Regulatory constraints & 2 \\
\hline Medium & 0.84 & 3.44 & Personal handicaps & 3 \\
\hline
\end{tabular}

Table (3) shows that the arithmetic averages ranged between (3.50-3.44), where the environmental obstacles came first with the highest arithmetic average of (3.50), while personal obstacles came in the last rank with an arithmetic average of (3.44), and the arithmetic mean for the obstacles As a whole (3.48).

The arithmetic averages and standard deviations for the study sample estimates were calculated on the items of each field separately, as they were as follows:

The first dimension: environmental constraints

Table (4) shows the arithmetic averages, standard deviations, and rank for the study sample estimates for each of the paragraphs of this dimension. 
Table (4) Arithmetic Averages, Standard Deviations, and Rank for Estimates of the Study Sample Members on Paragraphs After Environmental Constraints

\begin{tabular}{|c|c|c|c|c|c|}
\hline level & $\begin{array}{l}\text { standard } \\
\text { deviation }\end{array}$ & Mean & Paragraphs & Number & Rank \\
\hline Medium & .89 & 3.66 & $\begin{array}{l}\text { Lack of cooperation of the local community with the } \\
\text { school, as it raises new ideas for developing work }\end{array}$ & 4 & 1 \\
\hline Medium & .83 & 3.64 & $\begin{array}{l}\text { Weak material and moral support from the community } \\
\text { members and institutions for the ideas presented by the } \\
\text { school }\end{array}$ & 7 & 2 \\
\hline Medium & .94 & 3.60 & $\begin{array}{l}\text { Parents insist on sticking to the usual routine methods and } \\
\text { resist the ideas that deviate from them. }\end{array}$ & 2 & 3 \\
\hline Medium & .86 & 3.56 & $\begin{array}{l}\text { Community confirmation of dependency and stereotypical } \\
\text { behavior. }\end{array}$ & 10 & 4 \\
\hline Medium & .89 & 3.53 & $\begin{array}{l}\text { The negative impact of the environment acquired by the } \\
\text { individual on the directions of his administrative } \\
\text { creativity. }\end{array}$ & 8 & 5 \\
\hline Medium & .93 & 3.50 & $\begin{array}{l}\text { Society customs and traditions prevent the introduction of } \\
\text { new unfamiliar ideas. }\end{array}$ & 1 & 6 \\
\hline Medium & .87 & 3.48 & $\begin{array}{l}\text { Weak media interest in expanding intellectual horizons } \\
\text { through thinking skills development programs. }\end{array}$ & 9 & 7 \\
\hline Medium & .87 & 3.43 & $\begin{array}{l}\text { Parents rejected the new, unfamiliar ideas of school work } \\
\text { progress. }\end{array}$ & 3 & 8 \\
\hline Medium & .86 & 3.40 & $\begin{array}{l}\text { The absence of open communication channels between the } \\
\text { school and the local community to find creative solutions }\end{array}$ & 6 & 9 \\
\hline Medium & 0.87 & 3.38 & $\begin{array}{l}\text { Criticism of new ideas, methods and activities in applying } \\
\text { the curricula by parents. }\end{array}$ & 5 & 10 \\
\hline Medium & 0.88 & 3.53 & \multicolumn{3}{|l|}{ Environmental constraints } \\
\hline
\end{tabular}

Table (4) shows that the arithmetic averages ranged between (3.66-3.38), as paragraph (4) stated that "the lack of cooperation of the local community with the school in its new ideas for developing work" came first and with an average of (3.67) While paragraph (5) which reads "Criticism of new ideas, methods and activities in applying curricula by parents" came in the last rank with an average of (3.39). The mean of the environmental dimension as a whole was (3.53), and this means that all paragraphs of this dimension were of an average degree in estimating the degree of their existence as obstacles to administrative creativity in government schools from the viewpoint of the study sample individuals. This result is attributed to the weak relationship between the school and the local community due to the absence of direct contact between the school and the community, as well as the impact of the environment, customs, traditions and methods of socialization, and the lack of institutions and individuals to carry out their duties to serve the school and cooperate with it, and this result agreed with the study of Al-Harami (2003) and the study of Al-Harithi ( 2012) and Al-Omari Study (2015).

The second dimension: organizational obstacles

Table (5) shows the arithmetic averages, standard deviations, and rank for the study sample estimates for each of the paragraphs of this dimension. 
Table (5) Arithmetic Averages, Standard Deviations, and Rank of the Study Sample Estimates for Paragraphs after Organizational Constraints

\begin{tabular}{|c|c|c|c|c|c|}
\hline level & $\begin{array}{l}\text { standard } \\
\text { deviation }\end{array}$ & Mean & Paragraphs & Number & Rank \\
\hline Medium & 1.35 & 3.60 & $\begin{array}{l}\text { Scarcity of programs and training courses on creativity and } \\
\text { innovation skills at work. }\end{array}$ & 3 & 1 \\
\hline Medium & .79 & 3.58 & $\begin{array}{l}\text { Lack of moral incentives for the owners of new positive } \\
\text { ideas. }\end{array}$ & 8 & 2 \\
\hline Medium & .76 & 3.57 & $\begin{array}{l}\text { Lack of officials' appreciation of the importance of the } \\
\text { team as a way to suggest new ideas and appropriate } \\
\text { solutions to problems }\end{array}$ & 5 & 3 \\
\hline Medium & .77 & 3.56 & Confirm the literal commitment to applying the laws. & 7 & 4 \\
\hline Medium & .73 & 3.54 & Limited freedom to complete school work. & 2 & 5 \\
\hline Medium & 1.06 & 3.52 & $\begin{array}{l}\text { Lack of encouragement to experiment with new methods } \\
\text { of running a school and solve its problems }\end{array}$ & 6 & 6 \\
\hline Medium & .98 & 3.48 & $\begin{array}{l}\text { The administrative system lacks sufficient flexibility to } \\
\text { develop the work. }\end{array}$ & 4 & 7 \\
\hline Medium & .90 & 3.46 & Difficulty contacting and communicating with officials. & 1 & 8 \\
\hline Medium & .93 & 3.42 & $\begin{array}{l}\text { Lack of interest in the continuous development of business } \\
\text { policies, systems and regulations. }\end{array}$ & 10 & 9 \\
\hline Medium & 1.35 & 3.38 & $\begin{array}{l}\text { Lack of effective communication between school } \\
\text { personnel and their colleagues in other schools. }\end{array}$ & 9 & 10 \\
\hline Medium & 0.96 & 3.52 & Organizational constraints & & \\
\hline
\end{tabular}

Table (5) shows that the arithmetic averages ranged between (3.30-3.38), as paragraph (3) states that "scarcity of programs and training courses on creativity and innovation skills at work" came first and with an average of (3.61), Whereas, Paragraph No. (9) said, "The lack of effective communication between school employees and their colleagues in other schools." In the last rank, with an average score of (3.40). The mean of the organizational dimension as a whole was (3.52), and this means that all paragraphs of this dimension were of an average degree in estimating the degree of their existence as obstacles to administrative creativity in government schools from the point of view of the study sample individuals. This result is attributed to the feeling of the members of the study sample being the lack of encouragement of administrative creativity by the responsible authorities, and the failure to create an appropriate environment for it. This may also be due to the lack of courses and training programs on creativity and innovation skills at work, and this result was consistent with the study of Al-Harami (2003) and the study of Al-Harthi (2012) and the study of Al-Omari (2015).

The third dimension: personal handicaps

Table (6) shows the arithmetic averages, standard deviations, and rank for the study sample estimates for each of the paragraphs of this dimension.

Table (6) Arithmetic Averages, Standard Deviations, and Rank of the Study Sample Estimates for Paragraphs After Personal Disabilities

\begin{tabular}{|l|l|l|l|l|l|}
\hline level & $\begin{array}{l}\text { standard } \\
\text { deviation }\end{array}$ & Mean & Paragraphs & Number & Rank \\
\hline Medium & .79 & 3.62 & Personal keenness to adhere to the instructions. & 9 & 1 \\
\hline Medium & .74 & 3.60 & Officials' resistance to change. & 5 & 2 \\
\hline Medium & .83 & 3.58 & Reluctance to present unfamiliar ideas. & 3 & 3 \\
\hline Medium & .76 & 3.51 & $\begin{array}{l}\text { Poor confidence in others leads to rejection of their } \\
\text { suggestions. }\end{array}$ & 8 & 4 \\
\hline Medium & 1.03 & 3.50 & $\begin{array}{l}\text { The belief that adherence to established laws at work } \\
\text { leads to success and distinction. }\end{array}$ & 5 \\
\hline Medium & .91 & 3.48 & Focusing effort on hard and neglecting minor problems. & 7 & 6 \\
\hline Medium & .85 & 3.45 & $\begin{array}{l}\text { Avoid asking about known things for fear of } \\
\text { embarrassment. }\end{array}$ & 6 & 7 \\
\hline Medium & .88 & 3.44 & $\begin{array}{l}\text { Being satisfied with one idea and mastering it is better } \\
\text { than having multiple ideas. }\end{array}$ & 5 & 8 \\
\hline Medium & .88 & 3.43 & Reluctance to present unfamiliar ideas. & 4 & 9 \\
\hline Medium & .74 & 3.40 & Lack of interest in finding new solutions to problems. & 10 & 10 \\
\hline Medium & 0.84 & 3.44 & Personal handicaps & \\
\hline
\end{tabular}

Table (6) shows that the arithmetic averages ranged between (3.62-3.40), where paragraph No. (9) stipulates

"personal concern for adherence to the instructions." In the first place with an arithmetic average of (3.59), while 
paragraph No. ( 10) The text reads: "Lack of interest in finding new solutions to problems." Last rank, with an average of (3.28). The arithmetic mean for the dimension of personal obstacles as a whole was (3.44), which means that all paragraphs of this dimension were of an average degree in estimating the degree of their existence as obstacles to administrative creativity in government schools from the point of view of the study sample individuals. This result is attributed to the commitment of workers to instructions, regulations and laws, their concern to cover their duties and lack of interest in finding new solutions to the problems facing them, and this result agreed with the study of Al-Harami (2003) and Al-Harithi study (2012) and Al-Omari study (2015).

The second question: Are there statistically significant differences at the degree of significance $(0.05 \geq \alpha)$ between the averages of government school principals in the university district regarding the obstacles to administrative creativity attributable to the variables (gender, experience)?

This question was answered as follows:

1. Gender variable:

Arithmetic averages and standard deviations for administrative creativity obstacles have been calculated among principals of public schools in the university district from their point of view, according to the gender variable, and a t-test has been applied and table (8) shows that.

Table (8) arithmetic averages and standard deviations for obstacles to administrative creativity among principals of public schools in the university district, and the t-test, depending on the gender variable

\begin{tabular}{|l|l|l|l|l|l|l|}
\hline $\begin{array}{l}\text { Dimensions of obstacles to } \\
\text { administrative creativity }\end{array}$ & gender & Number & Mean & $\begin{array}{l}\text { standard } \\
\text { deviation }\end{array}$ & $\begin{array}{l}\text { Value } \\
\text { of t }\end{array}$ & $\begin{array}{l}\text { Degree } \\
\text { significance }\end{array}$ \\
\hline \multirow{2}{*}{ Personal handicaps } & Male & 50 & 3.48 & 0.67 & 3.466 & $* 0.016$ \\
\cline { 2 - 8 } & female & 55 & 3.37 & 0.78 & & \\
\hline \multirow{2}{*}{ Organizational constraints } & Male & 50 & 3.85 & 0.54 & 3.33 & $* 0.000$ \\
\cline { 2 - 7 } & female & 55 & 3.75 & 0.59 & & \\
\hline \multirow{2}{*}{ Environmental constraints } & Male & 50 & 3.88 & 0.43 & 0.956 & 0.265 \\
\cline { 2 - 7 } & female & 55 & 3.76 & 0.36 & & \\
\hline Total score & Male & 50 & 3.73 & 0.54 & 2.584 & $* 0.000$ \\
\cline { 2 - 7 } & female & 55 & 3.62 & 0.57 & & \\
\hline
\end{tabular}

The results in Table (8) indicate the presence of statistically significant differences at $(0.05 \geq \alpha)$ for administrative creativity obstacles in government schools in the university district, according to the gender variable, based on the calculated value of (T) as it reached (2.584) and a degree of significance (0.000) ), As well as in most areas where the difference was in favor of males in evidence of their high arithmetic averages, and this can be explained that some studies have found that creativity in females is more than in males because females are more related to the profession of education and more loyal to it and this can be due to the nature of the culture that prevails Arab society in general, and Jordanian society in particular It explains in the light of what is owned by female administrative skills, and personal characteristics Kalhamas and the desire to work and achievement and understanding of the role assigned to them and care to show accuracy at work in front of officials.

This result was consistent with Al-Harami study (2003) and Al-Omari study (2015), and it differed with AlHarthi study (2012) and Al-Tayeb study (2015), which concluded that there are no statistically significant differences attributed to sex.

2. Experience variable:

Mathematical averages and standard deviations for administrative creativity impediments were calculated among principals of public schools in the university district, according to the variable of experience, and table (9) shows that. 
Table (9) arithmetic averages and standard deviations for obstacles to administrative creativity among directors of government schools in the university district, according to the variable

\begin{tabular}{|l|l|l|l|}
\hline Dimensions of obstacles to administrative creativity & Experience & mean & standard deviation \\
\hline \multirow{5}{*}{ Personal handicaps } & Less than 5 years & 3.45 & 0.72 \\
\cline { 2 - 4 } & From 5 to less than 10 years & 3.26 & 0.61 \\
\cline { 2 - 4 } & 10 years and over & 3.20 & 0.76 \\
\cline { 2 - 4 } & Total & 3.30 & 0.69 \\
\hline \multirow{5}{*}{ Organizational constraints } & Less than 5 years & 3.73 & 0.60 \\
\cline { 2 - 4 } & From 5 to less than 10 years & 3.76 & 0.58 \\
\cline { 2 - 4 } & 10 years and over & 3.68 & 0.75 \\
\cline { 2 - 4 } & Total & 3.72 & 0.64 \\
\hline \multirow{5}{*}{ Environmental constraints } & Less than 5 years & 3.93 & 0.68 \\
\cline { 2 - 4 } & From 5 to less than 10 years & 3.76 & 0.64 \\
\cline { 2 - 4 } & 10 years and over & 3.88 & 0.65 \\
\cline { 2 - 4 } & Total & 3.85 & 1.65 \\
\hline \multirow{5}{*}{ Total score } & Less than 5 years & 3.70 & 0.66 \\
\cline { 2 - 4 } & From 5 to less than 10 years & 3.59 & 0.61 \\
\cline { 2 - 4 } & 10 years and over & 3.58 & 0.72 \\
\cline { 2 - 4 } & Total & 3.62 & 0.66 \\
\hline
\end{tabular}

It is noted from Table (9) that there are apparent differences between the arithmetic averages for the obstacles of administrative creativity among principals of government schools in the university district, according to the variable of experience, as the owners of the category (less than 5 years) got the highest arithmetic average of (3.70), and the owners of the category (From 5 to less than 10 years), at the second rank with an average score of (3.59), and finally, the mean for a category (10 years or more) came to (3.58), and to determine whether the differences between the averages are statistically significant at the degree of significance $(0.05 \geq \alpha)$ One way ANOVA was applied, and the results of the analysis of variance came as shown in Table (10):

Table (10) Analysis of mono-variance to find the significance of differences for the reality of administrative creativity among high school principals in the Kasbah of Zarqa, according to the variable

\begin{tabular}{|c|c|c|c|c|c|c|}
\hline $\begin{array}{l}\text { Dimensions } \\
\text { of obstacles } \\
\text { to } \\
\text { administrati } \\
\text { ve } \\
\text { creativity }\end{array}$ & $\begin{array}{l}\text { Source } \\
\text { contrast }\end{array}$ & $\begin{array}{l}\text { Sum of } \\
\text { squares }\end{array}$ & $\begin{array}{l}\text { Degrees of } \\
\text { freedom }\end{array}$ & $\begin{array}{l}\text { Average } \\
\text { squares }\end{array}$ & $\begin{array}{l}\text { Value of } \\
\text { F }\end{array}$ & $\begin{array}{l}\text { Degree of } \\
\text { significance }\end{array}$ \\
\hline \multirow[t]{3}{*}{$\begin{array}{l}\text { Personal } \\
\text { handicaps }\end{array}$} & $\begin{array}{l}\text { Between } \\
\text { groups }\end{array}$ & 7.45 & 2 & 4.36 & 10.08 & 0.001 \\
\hline & Within groups & 320.67 & 102 & 0.545 & & \\
\hline & Total & 329.12 & 104 & & & \\
\hline \multirow[t]{3}{*}{$\begin{array}{l}\text { Regulatory } \\
\text { constraints }\end{array}$} & $\begin{array}{l}\text { Between } \\
\text { groups }\end{array}$ & 1.37 & 2 & 0.75 & 1.735 & 0.153 \\
\hline & Within groups & 170.57 & 102 & 0.36 & & \\
\hline & Total & 171.94 & 104 & & & \\
\hline \multirow{3}{*}{$\begin{array}{l}\text { Environme } \\
\text { ntal } \\
\text { constraints }\end{array}$} & $\begin{array}{l}\text { Between } \\
\text { groups }\end{array}$ & 1.01 & 2 & 0.60 & 1.386 & 0.344 \\
\hline & Within groups & 188,62 & 102 & 0.48 & & \\
\hline & Total & 23.45 & 104 & & & \\
\hline
\end{tabular}

The results in Table (10) indicate that there are statistically significant differences at $(0.05 \geq \alpha)$ for administrative creativity obstacles among principals of public schools in the university district, according to the variable of experience, only after personal obstacles. To find out the sources of these differences, a Shafi test was used for the dimensional comparisons. Table (11) shows that: 
Table (11). Cheval test for the dimensional comparisons of the significant differences due to the variable of experience

\begin{tabular}{|l|l|l|l|l|l|}
\hline Obstacles to administrative creativity & Experience & Mean & $\begin{array}{l}10 \\
\text { years } \\
\text { and } \\
\text { over }\end{array}$ & $\begin{array}{l}\text { Less } \\
\text { than 5 } \\
\text { years }\end{array}$ & $\begin{array}{l}\text { From 5 to less } \\
\text { than } 10 \text { years }\end{array}$ \\
& & & 3.20 & 3.26 & 3.45 \\
\hline Personal handicaps & Less than 5 years & 3.45 & - & $.76^{*}$ & $* 0.63$ \\
\cline { 2 - 6 } & From 5 to less than 10 years & 3.26 & & - & 0.15 \\
\cline { 2 - 6 } & \multirow{2}{*}{10 years and over } & 3.20 & & & - \\
\hline
\end{tabular}

The difference is statistically significant at (0.05)

From Table No. (11), there are statistically significant differences at $(\alpha=0.05)$ between the averages of those with less than 5 years of experience and the mean of those with 10 years or more over the distance of personal disabilities.

It also showed that there are statistically significant differences at the level $(\alpha=0.05)$ between the averages of the estimates of those with experience from 5 to less than 10 years and the mean of the estimates of those with experience of 10 years or more, after the personal disabilities. There were no statistically significant differences at the level $(\alpha=0.05)$ between the averages of the estimates of those with experience less than 5 years and the mean of the estimates of those with experience from 5 to less than 10 years. Which means that the degree of the presence of personal handicaps in estimating those with the last 10 years or more is less than the experience of less than 5 years and from 5 to less than 10 years. While estimates of the two groups of experience do not differ from 5 to less than 10 years and less than 5 years, to the degree of the existence of these obstacles. The results of this study differ with the findings of the study (Fuentes, 1996) and Al-Harthi study (2012).

\section{Recommendations:}

In light of the researcher's findings to:

1. Working to link social and cultural institutions of society in order to join efforts to contribute to educating community members about the importance of creativity.

2. Organizing training programs and courses to develop creativity skills.

3. Work to reduce the obstacles that hinder access to creativity.

\section{References}

\subsection{Arabic references}

- Anjoud, Shehadeh Balwani (2008). The role of school administration in developing creativity in government schools in the governorates of northern Palestine and their obstacles from the viewpoint of their principals, Master Thesis, An-Najah National University, Palestine.

- $\quad$ Perfume, Souad (2015). Empowerment: administrative creativity: a field study on a sample of Qutub 2 workers at the University of Kassadi, Mirbah and Ouargla. Unpublished Master Thesis, University of Kassadi Merbah, Ouargla, Algeria.

- Jamaan, Badria (2014). Obstacles in exercising the leadership role of school principals in the Al-Baha region and ways to confront them from their point of view. Unpublished Master Thesis, Al-Baha University: Saudi Arabia.

- Al-Harthi, Meshaal Bin Mubarak Ayed (2012). The reality of applying the elements of administrative creativity and its most prominent obstacles to principals of secondary schools in Jeddah Governorate, Master Thesis, Umm Al-Qura University, Saudi Arabia.

- Khasawneh, Akef Lutfi, (2011). Creativity and Innovation Department in Business Organizations, 1st Floor, Dar Al-Hamid for Publishing and Distribution, Amman - Jordan.

- Al-Zayoud, Majed Muhammad, (2012). The degree of information technology practice and its relationship to administrative creativity of government secondary school principals in the Kingdom of Bahrain, Journal of Educational and Psychological Sciences, Volume 13, No. 2, p. 12.

- Al-Otaibi, Suhair (2018). Obstacles to administrative creativity among leaders of government schools in Afif Governorate, Arab Foundation for Scientific Consultation and Human Resources Development, 5 (62), 196-211.

- Al-Omari, Kholoud (2015). Obstacles to administrative creativity among school principals in the Department of Education, Al-Makhwah, from their point of view. Unpublished Master Thesis, Al-Baha University: Saudi Arabia.

- Al-Enezi, Omair (2018). Obstacles to Administrative Creativity among Academic Leadership at Northern 
Borders University, Kingdom of Saudi Arabia, Journal of Education - Al-Azhar University, 1 (177), 402439.

- Al-Muhailbi, Abdul Aziz Saud, Al-Azmi, Mazana Saad, and Al-Qahtani, Abdul Mohsen Ayed, (2014). Organizational culture in public and private education schools in the State of Kuwait and its relationship to administrative creativity, Educational Journal, No. 110, pp. 15-17.

- Foreign referencesCastillo-Vergara, M., Galleguillos, N.B., Cuello, L.J., Alvarez-Marin, A., \& Acuña-Opazo, C. (2018). Does socioeconomic status influence student creativity? Thinking Skills and Creativity, 29, 142-152.

- $\quad$ Fasko, D. (2015). Education and creativity. Creativity Research Journal, 13(3/4), 317- 327.

- Fuentes , Nancy , DC (1996). Improvement Strategies at Six Culturally Different School, Office of Education Research and Improvement (ED), Washington.

- Handoyo, S. (2011). Measurement of servant leadership as an alternative leadership in higher education Institutions in the period of organizational change. Hubs-Asia, 9(2), 131.

- Hsiao, H. C., Chang, J. C., \& Chen, S. C. (2014). The influence of support for innovation on organizational innovation: Taking organizational learning as a mediator. Asia Pacific Education Review, 23, 463. https:// doi.org/10.1007/s40299-013-0121-x.

- Kempa, R. (2015). Principal leadership. Yogyakarta: Waves.

- Mayfield, M., \& Mayfield, J. (2008). Leadership techniques for nurturing worker garden variety creativity. Journal of Management Development, 27(9), 976-986.

- Plucker, J. A., Beghetto, R. A., \& Dow, G. T. (2004). Why isn't creativity more important to educational psychologists? Potentials, pitfalls, and future directions in creativity research. Educational Psychologist, 39(2), 8396.

- $\quad$ Plucker, J. A., Kaufman, J. C., \& Beghetto, R. A. (2015). What we know about creativity. Washington, DC: P21 Retrieved from http://www.p21.org/our-work/4cs-researchseries/creativity.

- Rosenfield, K. (2015). The best US architecture schools . ArchDaily. Retrieved from http://www.archdaily.com/776718/the-best-us-architectureschools-for-2019-are.

- Sagala, S. (2013). Professional capabilities of teachers and education personnel. Bandung: Alfabeta.

- Talbot, R. J. (1997). Taking style on board (or how to get used to the idea of creative adaptors and uncreative innovators). Creativity and Innovation Management, 6(3), 177-184. doi:10.1111/1467-8691.00066.

- Toyotok, Esefhakan (2016). School leaders Innovation managements \& organizational stress: A relational Model study. Universal Journal of Educational Research 4(12A): 173-179.

- Yuliana, L. (2007). The role of principals in developing creative culture teachers of physical education subjects. Yogyakarta State University. 